\title{
When politicians do not care for the policy: Street-level compliance in cross-agency contexts
}

Céline Mavrot ${ }^{\mathrm{a}, \mathrm{b}}$, Susanne Hadorn ${ }^{\mathrm{a}}$

${ }^{a}$ KPM Center for Public Management, University of Bern

${ }^{b}$ David Geffen School of Medicine, University of California - Los Angeles (UCLA)

\section{Pre-Layout/Pre-Print Version - This is not the latest version, please refer to:}

Mavrot Céline, Hadorn Susanne (2021). "When Politicians do not Care for the Policy: Street-level Compliance in Cross-Agency Contexts", Public Policy \& Administration, early online. DOI: $\underline{10.1177 / 0952076721996516}$

\begin{abstract}
The non-implementation of political decisions is a major challenge of contemporary political life. Policy analysis has devoted careful attention to implementation gaps resulting from administrative noncompliance with political orders. However, the fact that political authorities actually want to enforce all policies should not be taken as granted. This article proposes a conceptual model that systematically accounts for cross-agency divergence and convergence processes both at the political and at the street levels. We find that in inter-sectoral policies, dissent between different heads of agencies (political level) or between groups of implementing bureaucrats (street level) rather than dissent between the political and the street-level can be a major cause of non-compliance. Based on a comparative dataset on the implementation of the smoking ban in 12 Swiss states, the article analyzes cross-agency fragmentation processes. It advocates a stronger dialogue between street-level bureaucracy and policy coordination literatures, and nuances the conceptualization of (non)compliance in a cross-agency context.
\end{abstract}

Keywords: street-level bureaucrats, policy compliance, street-level divergence, cross-agency coordination, cross-agency competition 


\section{Introduction}

Policy compliance and the conditions under which the designing and implementation structure of a public intervention could enhance compliance has received much attention in the policy analysis field. Research is often "motivated by the question of how to better align policymakers' intentions with street-level implementation actions" (Gofen, 2014: 477) and has thus devoted much attention to the conflicting goals between policymakers and implementers, identifying various ways by which the political will can be transposed, distorted or even ignored by the street-level bureaucrats (SLBS) (May and Wood, 2003; Meyers and Vorsanger, 2003). The discretion of bureaucrats in implementing policies has received vast attention (Tummers and Bekkers, 2014), whereby the discussion about how and to which extent politics has to control bureaucrats' discretion has historically held prominent place in public administration scholarly debate (Rosser and Mavrot, 2017). However, the assumption that policymakers' intentions represent a unified and coherent will is far from being an empirical reality (Neveu, 2015). The questions of interagency coordination (Peters, 2006), rivalry (Hassenteufel, 2003: 5) and fragmentation (Gortmaker et al., 2011) as well as conflicting priorities (Palley, 2006) or the lack of political agreement on a given issue (Torenvlied, 1996) have also been identified as core challenges.

The potential causes for non-compliance thus not only lie at the street-level itself, but may sometimes be rooted in interagency dissents at the political level. Based on these insights, the core question this paper examines through an empirical investigation is how different cross-agency configurations influence street-level compliance. We argue that the literature on policy compliance can benefit from the literature on policy coordination. Taking into account the complex interplays between different administrative agencies involved in the implementation of a policy, and the possible political dissents at the head of agencies, allows for a non-linear understanding of policy compliance.

This issue is topical because most of crucial contemporary societal challenges require inter-sectoral interventions and are strongly affected by cross-agency divergence issues. In our example, the focus is on the necessary and often lacking cooperation between health, security, economic, and building 
and transport agencies in the enforcement of smoking bans. The article focuses on two overlooked aspects of policy (non-)compliance. First, it investigates cross-agency divergences at the political level, at the light of conflicting policy clientele and conflicting policy objectives. Second, we focus on the street-level by analyzing the relationships between SLBs from different agencies whose cooperation is required to enforce the policy. To successfully implement the smoking ban, health bureaucrats need the cooperation of other agencies who hold law and order responsibilities (police, labor inspectors, food and hygiene inspectors) and do not always perceive the enforcement of the ban as a priority. Thus, the article explores the specificities of policy subsystems where the implementation responsibility (i.e., health bureaucrats) is uncoupled from the implementation capacities (i.e., security and economy bureaucrats). A conceptual model that depicts (non-)compliance in situations of crossagency indifference, divergence or convergence is introduced, demonstrating the necessity of adopting an inter-agency perspective.

The first section of the article draws on the street-level bureaucracy and implementation literature to gain insights on the factors influencing policy (non-)compliance. After exposing the research design, we turn to a comparative analysis of the smoking ban enforcement within twelve Swiss subnational units, to examine cross-agency implementation dynamics. These results are then discussed by linking the SLB literature with research on policy coordination. The article ends with conclusive remarks about policy compliance and identifies areas for further research regarding cross-agency policy analysis.

\section{Theoretical framework: Street-level bureaucrats and policy coordination}

\section{Street-level bureaucrats at the crossroads: The case for a relational approach}

Street-level bureaucrats are defined as frontline workers that are in direct contact with citizens and enjoy discretion and autonomy when performing their duties (Maynard-Moody and Portillo, 2010). As Michael Lipsky (1980: 13) has shown, "the position of street-level bureaucrats regularly permits them to make policy with respect to significant aspects of their interactions with citizens". The discretion 
component is a much discussed aspect of bureaucrats' activities and the possible gap between the political will and the effective implementation actions has been widely documented.

Policy compliance can be described as the effective execution of a policy by implementation agents the way it had been set out by politics. Thereby, street-level non-compliance rarely takes the form of direct rejection or disobedience, but is commonly manifested in daily micro practice such as deviance, negotiation, rule adaptation or the prioritization of some tasks at the expense of others. In this sense, it appears more appropriate to label the (partially) non-compliant actions of implementation actors as street-level divergence (Gofen, 2015). Several factors were found to foster non-compliant behavior: For instance, SLBs tend to prioritize the expected value for citizens over the compliance with the political will (Tummers et al., 2015), whereas decreasing bureaucratic capacity and excessive workload also reduce policy compliance (Huber and McCarty, 2004; Goodman et al., 2007). Moreover, politicians and bureaucrats can have conflicting political preferences, affecting SLBs' motivation to enforce the respective policies (Torenvlied, 1996).

\section{Cross-agency fragmentation, coordination and rivalry}

The large body of literature on street-level divergence, mainly focused on dissent from SLBs with the public authorities, whereby the latter were often being treated as a unified collective actor. However, cross-agency fragmentation and concurrence complicate the picture. Both vertical (i.e., hierarchical) and horizontal (i.e., inter-organizational) policy cooperation mechanisms must be taken into account (Ayres and Stafford, 2012: 337). Indeed, the way interconnected issues are (de)coupled across agencies can have a crucial impact on the policy outcome (Hernes, 2020). In cases of cross-agency fragmentation, different groups of SLBs have to coordinate their action, although not belonging to the same hierarchical chain of command. This creates situations with a potentially insufficiently clear division of tasks as well as diffused accountability and control mechanisms (Molenveld et al., 2020a: 2). Hence, cross-agency coordination might be the answer. However, a close empirical attention 
should be given to cross-agency coupling processes, because they can be genuinely substantial, or serve a purely symbolic function for political purposes (Hernes, 2020).

In the case of policy programs, one agency is likely to be the lead agency responsible for the program, whilst the cooperation of partner agencies is needed because the latter hold the enforcement monopoly regarding some aspects of the program. For instance, health agencies are likely to be the lead agencies in enforcing tobacco control, whilst the department of justice is a partner agency because its SLBs (i.e., police officers) have the exclusive right to control whether clients smoke in bars.

The awareness that conflicts may arise between different sectors about policies that require collaboration is not new to the literature on policy coordination (Trein, 2017a). Such coordination mechanisms can vary from "loosely coupled networks" to highly formalized joint service delivery (Hulst and van Montfort, 2012: 123). According to Trein (2017b), two factors influence the degree to which individuals or groups from different policy sectors are coupled: distinctiveness and responsiveness. Distinctiveness, meaning that policy sectors are allocated to different institutions such as "a horizontal separation into different ministries and administrations", tends to decrease the intensity of coupling (Trein, 2017b: 422). Governmental structures where policy sectors are thematically entrenched into different administrations thereby complicates coupling processes. Responsiveness, which increases coupling, captures whether there exists a cooperation between actors from different policy sectors "to achieve common policy output" (Trein, 2017b: 422). Using the SLB-terminology, responsive actors strive for cross-agency convergence whereas non-responsive actors create cross-agency divergence. In addition, horizontal cooperation mechanisms face numerous challenges, like accountability issues (Peters, 2006) or organizational routines (Peters, 2015).

Moreover, the involved agencies can be led by politicians of different parties, which might add a partisan competition component to the process (Busch, 2008). This may lead to a lack of top-down incentives for cross-sector cooperation. Moreover, as Torenvlied (1996: 25) has shown, "[p]olitical 
consensus does not generally enhance compliance-as is often asserted-but does so conditional upon a low agency salience", i.e., when bureaucrats do not have a specific professional incentive for policy divergence such as for instance conflicting professional norms or an excessive workload. In contrast, high agency salience and/or cross-agency political fragmentation can be seen as factors increasing the odds of street-level divergence.

\section{A conceptual model for policy compliance in cross-agency configurations}

Based on these theoretical considerations, a conceptual model depicting the possible paths of policy implementation in cross-agency contexts is proposed in Figure 1. This model draws on the theoretical complexity detailed above. On the one hand, it accounts for the fact that although formally agreeing on a policy program, policymakers themselves can actually aim at implementation or in the contrary impede it (cross-agency policy convergence or divergence). On the other hand, the model also accounts for the interrelations between different groups of street-level bureaucrats at the delivery level (cross-agency street-level convergence or divergence). Hence, cross-agency convergence is defined as the willingness of given agencies to collaborate around a policy or a program led by other agencies. Importantly, the political will is not conceptualized as unified, but as the fragmented result of interagency rivalries or diverging priorities. Moreover, the conceptual model accounts not only for political convergence or divergence, but also includes the possibility of political indifference at the head of agencies. In cases of street-level convergence, a collaboration is established between bureaucrats of two or more distinct agencies at the lower governance level. In cases of street-level divergence, the partner agencies do not prioritize the request of the lead agency. To sum up, the model focuses on: a) inter-agency cases and the related policy games at the political and street levels, b) the possibility of political indifference. We formulate the following expectations that are examined empirically in the next section:

Expectation 1: Cross-agency political convergence fosters street-level convergence and policy compliance by giving a clear and consistent mandate to the different groups of SLBs. 
Expectation 2: Cross-agency political divergence hampers street-level convergence and policy compliance by setting conflicting priorities for the different groups of SLBs.

Expectation 3: The absence of any explicit political directive (political indifference) may lead to either policy compliance or non-compliance, depending on the SLBs capacity to create bottom-up streetlevel convergence.

Expectation 4: In case of political indifference, street-level convergence is less likely to happen when there is a high agency salience on the issue.

Figure 1: Conceptual Model of Cross-Agency Relations during Policy Implementation

\begin{tabular}{|c|c|c|c|}
\hline 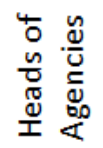 & $\begin{array}{l}\text { Political Convergence } \\
\text { Explicit support of policy }\end{array}$ & $\begin{array}{l}\text { Political Indifference } \\
\text { No positioning }\end{array}$ & $\begin{array}{l}\text { Political Divergence } \\
\text { Explicit blockage of policy }\end{array}$ \\
\hline 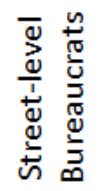 & $\begin{array}{l}\text { Street-level Convergence } \\
\text { Cross-agency cooperation } \\
\text { Alliance building }\end{array}$ & & $\begin{array}{r}\text { Street-level Divergence } \\
\rightarrow \quad \text { Cross-agency rivalry } \\
\text { Blockage }\end{array}$ \\
\hline 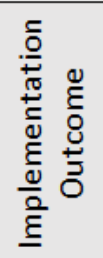 & COMPLIANCE & & NON-COMPLIANCE \\
\hline
\end{tabular}

\section{Research Design}

\section{Data, Method and Operationalization}

The comparative analysis is based on a most similar systems design and uses data (collected between 2012 and 2018) from the smoking ban enforcement in seven German-speaking and five Frenchspeaking Swiss states (i.e., the cantons, subnational governmental units) ${ }^{1}$. A comparison of implementation processes in Swiss states is particularly suitable for most similar systems designs, since macro contextual factors and the institutional design are stable, allowing for a robust

\footnotetext{
${ }^{1}$ The Swiss federal state includes twenty-six cantons. All Swiss cantons have their own parliament, government and administration.
} 
comparison of the conditions that vary across the states (Sager and Thomann, 2017). The examined smoking policies are all implemented within the same national political system, whilst the actor configurations and the specific policy settings vary from state to state. The data was collected within a research and evaluation project assessing the effect of a tobacco control policy reform from 2012 that took the form of non-mandatory prevention programs: subnational governments could implement the new program at the local level in exchange for national seed money. The analyzed subnational policies thus represent all the cases of an opportunity sample, made of 12 voluntary states who had chosen to launch a program ${ }^{2}$. We analyzed the designing and three years of implementation of each subnational policy. The multiple case design of our study allows for a high robustness of the results, with a comparison of 12 governance units.

The data include 38 interviews with officials from the health, security, economic and/or the building and transport agencies of each state and members of non-governmental organizations and 72 selfevaluation reports about the smoking ban enforcement project(s) in each state (one to two concerned projects per state -public space and/or workplaces). The self-evaluation grids contained qualitative observations of the implementing actors and quantitative data related to the projects' outputs (e.g., number of inspections or sanctions) and the outcome attainment (i.e., target group response). Third, the policy history and context was assessed in each state through a content analysis of 13 years of parliamentary debates and a media analysis of six years on tobacco control. In addition, a set of subnational documentation (e.g., policy concepts, official reports) was analyzed. For a detailed display of the data, see Dataset and for an overview of the smoking ban projects, and the implementation actors, see Appendix.

We operationalized the core concepts as follows: We categorized SLB behavior as 'compliant' whenever the activities planned to enforce the smoking ban in public space and/or workplaces were implemented as defined in the policy concept. In projects where activities were not implemented as

\footnotetext{
${ }^{2}$ Fourteen states run a program, but two of them are not included in the study because they did not have any smoking ban project.
} 
planned, SLB behavior was categorized as 'non-compliant'. The categorization is based on a document analysis of the policy concepts to identify the set goals as well as on the self-evaluation reports and interviews providing information on the actual implementation. We therefore consider compliance at the implementation level, and not at the policy level in the sense of the overall policy performance. While compliance can depict the attitude of single groups of SLBs from one agency alone, convergence and divergence are relational concepts: they depict a relationship between groups of actors from different agencies (at the political or the street level).

Concerning the three mutually exclusive concepts convergence, divergence and indifference at the political level, we applied the following operationalization rules: Whenever SLB received explicit and uniform orders of the various heads of agencies involved to implement the policy, we categorized the situation as 'political convergence' (or "convergence at the political level"). In case of explicit orders of the head of a partner agency not to implement the policy or to prioritize other tasks at the expense of the policy analyzed, whilst the head of the lead agency supported implementation, the category "political divergence' was applied. Whenever the involved head of agencies issued no explicit order concerning the implementation of the policies, the category '(political) indifference' applied. Similarly, the category "street-level convergence" was chosen when bureaucrats from different agencies worked together to implement the policy of the lead agency (whether there was a political order to do so or not). "Street-level divergence" was used in the absence of such horizontal cooperation among SLBs from the lead and the partner agencies.

The categorization of SLB's activities as 'compliant' or 'non-compliant' was based on the selfevaluation reports. When $80 \%$ of the objectives were achieved (mostly quantitative objectives: number of controls per year), the situation was categorized as a compliance case; when less than $80 \%$ of the objectives were met, SLB's were considered as non-compliant. The categorization of political convergence, divergence and indifference was mainly based on the qualitative data extracted from the interviews. To avoid sensitivity bias (i.e., leeway in the categorization of each case), a variety of partners was interviewed in each state (implementation agents, external observers, program and 
project managers). The interview data from each state was cross-checked, and the number of interviewees per state ranged from 2 to 7.

Support or opposition to the policy at the political level were acknowledged when interviewees referred to concrete and explicit political attitudes in favor or against the enforcement of the policy. An example of a statement documenting support is: "after the police said 'it doesn't belong to our tasks' (...) the head of the [lead] agency conducted a governmental discussion (...) and this was then accepted" (public servant, Basel-City). An example of statement substantiating political obstruction was: "The politician at the head of the Health Department has already tried to contact the politician at the head of the Economy Department, but was unable to move the issue forward. The strategy of the steering body is now to wait for the next governmental reelection to thematize the issue again" (project leader, Fribourg). In the cases categorized as political indifference, interviewees declared there were no political signals pushing for or restraining the enforcement of the policy, and implementation actors felt free to decide themselves whether to prioritize this task or not. An example reads as follows: "I never felt any political pressure on my control activities (...). But obviously, the state depends a lot on the tobacco industry. (...) this is part of the political job to support the economy, that is normal (...) but the law is very clear and we apply it" (inspector, Neuchâtel). To ensure consistency and robustness, all categorizations were cross-checked by the two authors, who were also the one who gathered the data. The classification operations were held constant across the studied implementations years and the 12 states.

\section{The smoking ban in Switzerland: Adoption and implementation responsibilities}

The smoking ban in federal Switzerland provides an excellent case to examine cross-agency tensions in various local policy configurations. As has been noted, there is little literature studying tobacco control in Switzerland from a political science perspective (Trein, 2017c: 116). However, the strength of the tobacco industry and its influence on the policy processes in Switzerland have been documented (Lee and Glantz, 2001). A recent study has compared the enforcement of tobacco regulation in 14 Swiss states and highlights the importance of political, professional and economical factors in 
explaining local policy outcomes (Sager et al., 2020). At the legislative level, the Swiss Federal Passive Smoking Protection Act sets a smoking ban on public spaces and in bars and restaurants, however, allowing for certain exceptions (e.g., ventilated smoking rooms). The Federal Passive Smoking Protection Act also forbids smoking in closed spaces that serve as workplaces for more than one person. According to the division of tasks within Swiss federalism, the states have the responsibility to enforce the smoking ban on their territory. They must at least enforce the national legislation, but can also be stricter (e.g., no smoking rooms). Politically, the Federal Act is sometimes used as an excuse at the local level to adopt the minimal regulation and not to go beyond national requirements. However, the local configuration of actors and the history of the policy subsystem are decisive in understanding the policy outcome at the state level (Mavrot and Sager, 2018).

In this context, we define the subnational health agencies (collaborating with parapublic health organizations in some states) as the lead agency of the cantonal programs, and the other agencies whose involvement is necessary as the partner agencies. ${ }^{3}$ As Figure 2 shows, in ensuring an effective enforcement of the smoking ban, health agencies need the field work of the SLBs in charge of the control tasks (police, work inspectorate, hygiene inspectorate), who however do not fall within their scope of authority because they belong to other agencies (e.g., economy agency, security agency). The exact division of competences between these actors differ in each state (see Appendix). The heads of agencies are elected politicians from various parties and belong to the state government (five to seven government members per state). The bureaucrats in charge of the enforcement of the smoking ban in the various agencies are not politically appointed.

\footnotetext{
${ }^{3}$ We refer to these agencies by these general names in this paper, although their exact names and organizations vary from state to state.
} 
Figure 2: Dissociated Implementation Responsibility and Implementation Capacity

\section{National Government}

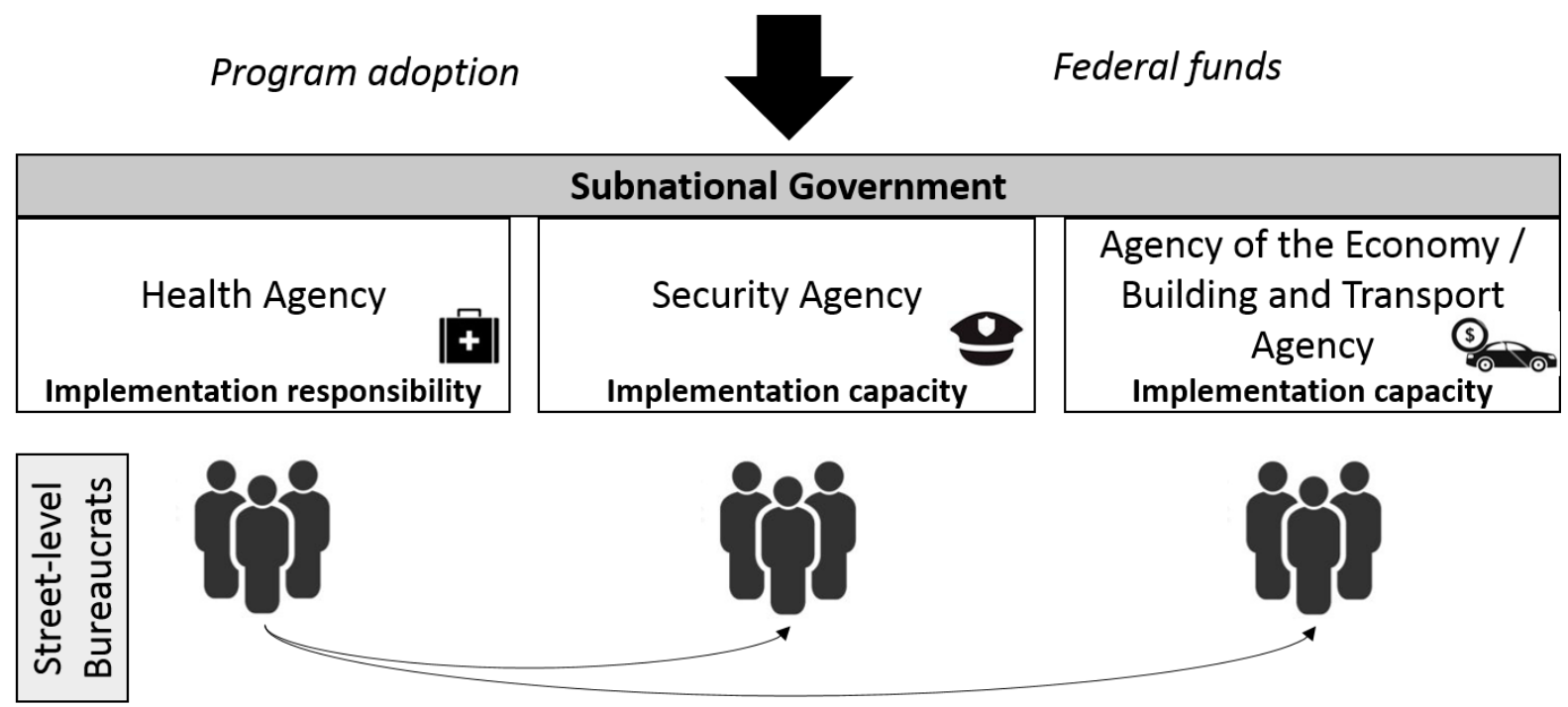

The following section details the case studies and asserts the conditions leading to policy compliance or non-compliance.

\section{Case study: Comparative cross-agency configurations}

Cross-agency political convergence. One of the first states (Basel-City) that passed a subnational smoking ban in 2008 (i.e., before the national legislation was introduced), exemplifies the case of cross-agency political convergence. When introduced, the ban caused considerable outrage among parts of the population and led to the formation of an association seeking loopholes in the legislation to continue smoking in public spaces. This was followed by years of struggle between the association and the state administration, which insisted on enforcing the ban. Here, implementation conflicts on the ground, the high public attention and the political salience of the issue are conditions which contributed to cross-agency political convergence. When the newly launched policy program was introduced in 2014 with the health agency's mandate to ensure the implementation of the smoking ban, the building and transport agency holding the implementation capacity had already established a rigorous control system that strongly reduced ban violations. Specifically, the head of the building and transport agency (a member of the Social Democratic Party (SDP)) had released extra resources 
to expand the control apparatus. Finally, the controls outperformed the initial policy objectives and were sufficient to ensure proper enforcement in the whole state. The decision to increase resources was taken after debates about the insufficient enforcement of the smoking ban had been held in the state parliament, whilst the responsible office had complained about the impossibility of implementing control without the necessary resources, shifting the blame for non-compliance to the head of agencies level.

The building and transport agency had itself taken measures to avoid blame resulting from noncompliant enforcement of this salient policy issue generating considerable media coverage in the state. Hence, the experience with previous implementation clashes and related blame avoidance reactions contributed to policy compliance, through an extra budget allocation process. The resulting shared political will of the two agencies to enforce the legislation led to a situation where all SLBS involved had a clear mission and sufficient resources to ensure compliance. Thereby, both agencies explicitly took credit for the strong law enforcement that finally led to a dissolution of organized resistance. The attribution of political credit not only to the lead agency in charge of the policy but also to the partner agency helping to enforce it therefore constitutes another important condition to foster inter-agency political convergence.

Cross-agency political divergence. A state of the French-speaking part of Switzerland with a strong public health administrative tradition and a historically right-wing liberal political anchorage (Vaud) exemplifies an open dispute between two administrative agencies for reasons of political priorities and administrative clientele. The health agency, led by a SDP politician, decided to enhance the enforcement of the smoking ban in the workplaces, after a public survey showed little compliance in the state. However, the health agency had no authority to conduct field inspections itself, and required the cooperation of the labor inspectorate located in the agency of economy, led by an elected member of the right-wing Liberal Radical Party (LRP). The inversion of political majorities at the head of the two agencies was an important condition for cross-agency divergence and, ultimately, non-compliance. The health agency tried to activate the agency of economy through the hierarchical way, at a political 
level. The agency of economy signaled that burdening the enterprises with more health-related inspections was not part of its priorities. Importantly, the electoral clientele of the LRP includes local business networks, which would have been affected by such controls. In the public positions of this party in the state (e.g., parliamentary debates), public health in general and tobacco control in particular are depicted as an unnecessary interference by the state in private behavior.

The fact that these two parties historically represent different political clienteles played as an important factor that hampered the enforcement of the smoking ban. Facing this blockage, the health agency did not attempt to contact the SLBs of the labor inspectorate directly as other states did. It was deemed politically too sensitive because of this clear-cut opposition, and a negative reaction from the inspectorate was anticipated. Thus, no specific controls regarding the smoking ban were made at workplaces in this state. In this case, a strongly rooted political rivalry exacerbated the perceived divergence between the respective missions of the agencies, making convergence around a common agenda difficult. The process was exactly the same in another state (Fribourg).

Cross-agency street-level divergence. A rural French-speaking state with little tobacco control experience (Jura) exemplifies policy divergence at the street level. In this state, the health agency was led by a SDP politician, while a LRP politician led the agency of economy, in charge of the hygiene inspectorate in the bars and restaurants. With the implementation of the new program, the health agency aimed at deploying controls in bars and restaurants, because the state was known for frequent infringements. Smoking in bars and restaurants was a deeply rooted habit in the state, where the tobacco industry was a significant economic and political player. Hence, the tobacco industry's strong presence and the lack of specialization in tobacco control were important conditions contributing to the weak policy compliance. According to the program managers, there was a relative indifference from the head of the agency of economy. At the street level, the hygiene inspectorate responsible for the controls of the ventilation in bars and restaurants demonstrated a passive but strong blockage. Because of these negative conditions, the SLBs put forward various arguments against the intensification of this enforcement task. 
First, they claimed that public health tasks did not belong to their mission, and that a strict separation of roles between the different groups of professionals would increase the credibility of their respective missions. Second, their priority was to control technical installations and food hygiene, to ensure customer safety. Finally, they argued that implementing random controls would be too costly and would hamper their other priority tasks. This example shows how a passive street-level divergence process can occur in spite of a formal but de facto weakly supported cross-agency policy agreement, and the challenges faced by a managing agency when it has no official authority over the relevant implementing actors. In a German-speaking state (Baselland), the situation regarding controls at workplace was very similar, with the health office responsible for the policy having no authority over the food inspectorate and labor inspectorate, who refused to collaborate.

Cross-agency street-level convergence. Finally, the analysis reveals a number of cases (St.Gallen, Zug, Uri, Solothurn, Valais, Neuchâtel) with cross-agency street-level convergence that led to policy compliance. In those cases, health agencies successfully collaborated with other agencies to control restaurants and the number of controls met or exceeded the policy objectives and ensured proper enforcement of the ban. There existed implicit approval of the planned implementation measures at the head of agencies in all these cases. However, support was much weaker than in the cases of policy convergence, taking the form of political indifference. In the state of Valais, a former bureaucrat of the health agency played a key role in creating street-level convergence since he later took office as a middle-ranked manager of the police in one of the state's biggest cities. He actively maintained his ties with his former colleagues and became the transmission belt between the health agency and the municipal police by taking part in an interagency working group on second-hand smoke as a representative of the police. Having a double professional credibility at the intersection of these two groups, he strongly — and successfully-pushed the municipal police to undertake control tasks related to the smoking ban that could not be performed by the health agency (e.g., controls in bars at night during their usual patrols). 
By framing the smoking ban enforcement as a question of law and order, this policy intermediary translated the public health needs towards its new colleague in the police, thereby generating crossagency street-level convergence around common objectives. Hence, the existence of intersecting actors able to relay the policy objectives across agencies and the issue framing as pertaining to the professional duties of different groups of SLBs also played as favorable factors. In other states such as St.Gallen, the seamless collaboration between SLBs of the lead and partner agencies was due to the successful establishment of a steering body gathering middle-managers of the different agencies. Pragmatic decisions were taken together in the steering committee, which was an important condition for convergence. Table 1 summarizes the conditions identified in the case studies leading to the four (non-)compliance configurations.

Table 1: Conditions Triggering (Non-)Compliance Configurations

\begin{tabular}{|c|c|c|c|c|}
\hline & $\begin{array}{l}\text { Head of Agency } \\
\text { Configuration }\end{array}$ & $\begin{array}{c}\text { Street-level } \\
\text { Configuration }\end{array}$ & Cases & Conditions \\
\hline $\begin{array}{l}\text { C } \\
0 \\
m \\
p \\
\text { I } \\
\text { i } \\
\text { a } \\
\text { n } \\
\text { c }\end{array}$ & $\begin{array}{l}\text { Cross-agency } \\
\text { political } \\
\text { convergence }\end{array}$ & $\begin{array}{l}\text { Street-level } \\
\text { convergence }\end{array}$ & Basel-City & $\begin{array}{l}\text { - } \text { Implementation clashes } \\
\text { - High political salience } \\
\text { - } \text { High media coverage about non-compliance } \\
\text { - } \quad \text { Boliticization } \\
\text { - } \text { head of agency } \\
\text { - Political blame avoidance reaction } \\
\text { the partitical credit attribution to the lead and } \\
\quad \text { ancies }\end{array}$ \\
\hline e & $\begin{array}{l}\text { Political } \\
\text { indifference }\end{array}$ & $\begin{array}{l}\text { Street-level } \\
\text { convergence }\end{array}$ & $\begin{array}{l}\text { St.Gallen } \\
\text { Solothurn } \\
\text { Valais } \\
\text { Neuchâtel } \\
\text { Baselland } \\
\text { Uri } \\
\text { Zug } \\
\text { Zug }\end{array}$ & $\begin{array}{l}\text { - } \quad \text { Low political salience } \\
\text { - } \quad \text { Policy perceived as legitimate } \\
\text { - } \quad \text { Cross-agency committees } \\
\text { - } \quad \text { Pragmatic solutions (integration of controls } \\
\text { in routine tasks of inspectorates) } \\
\text { - } \quad \text { Joint definition of enforcement measures } \\
\text { - } \\
\text { - }\end{array}$ \\
\hline $\begin{array}{l}\mathrm{N} \\
\mathrm{o} \\
\mathrm{n} \\
- \\
\mathrm{C} \\
\mathrm{o} \\
\mathrm{m}\end{array}$ & $\begin{array}{l}\text { Cross-agency } \\
\text { political } \\
\text { divergence }\end{array}$ & $\begin{array}{l}\text { Street-level } \\
\text { divergence }\end{array}$ & $\begin{array}{l}\text { Vaud } \\
\text { Fribourg }\end{array}$ & $\begin{array}{l}\text { - Competing parties at the head of } \\
\text { agencies } \\
\text { - Conflicting policy goals and political } \\
\text { clienteles (expected negative political } \\
\text { reward) } \\
\text { - } \begin{array}{l}\text { Policy perceived as illegitimate (smoking in } \\
\text { workplaces considered a private issue) }\end{array}\end{array}$ \\
\hline
\end{tabular}




\begin{tabular}{|c|c|c|c|c|}
\hline $\begin{array}{l}\mathrm{p} \\
\mathrm{l} \\
\mathrm{i} \\
\mathrm{a} \\
\mathrm{n} \\
\mathrm{c} \\
\mathrm{e}\end{array}$ & $\begin{array}{l}\text { Political } \\
\text { indifference }\end{array}$ & $\begin{array}{l}\text { Street-level } \\
\text { divergence }\end{array}$ & $\begin{array}{l}\text { Baselland } \\
\text { Thurgau } \\
\text { Jura }\end{array}$ & $\begin{array}{l}\text { - Strong economic interests against the policy } \\
\text { - low public acceptance } \\
\text { - Lack of administrative specialization } \\
\text { - Conflicting professional ethos (SLBs think } \\
\text { public health does not belong to their } \\
\text { mission) } \\
\text { - SLBs think a clear separation of tasks among } \\
\text { agencies increases everybody's credibility } \\
\text { - (Perceived) scarcity of resources: } \\
\text { prioritization of other policies }\end{array}$ \\
\hline
\end{tabular}

Note: Not all of the listed conditions, but different combinations of them were found in each state.

States with two enforcement projects are listed twice.

\section{Discussion: A refined understanding of policy compliance in cross-agency situations}

Policy implementation is the result of decisions made at the political level and actions taken by the implementing agencies (Pülzl and Treib, 2007). Thereby, tensions between politicians' decisions and the SLBs' discretion have been identified to be important drivers for non-compliance. This paper focuses on (non-)compliance in a multi-sector implementation context. The federal context of the case study allowed to compare highly similar initial situations in 12 governance units and to observe a diversity of cross-agency convergence and divergence processes, both at the political and street-level. However, similar phenomena might equally occur in non-federal political systems, as long as agencies responsible for the enforcement have to rely on other agencies without having authority over them. Borrowing from the literature on policy sector coordination, our results confirm that the institutional design or what has been called 'distinctiveness', i.e., the "horizontal separation into different ministries and administrations" (Trein, 2017b: 422), is crucial in understanding street-level compliance in cross-agency contexts.

Difficulties related to interagency collaboration exist because the agencies defend their own, often diverging, interests (Hustedt and Danken, 2017), sometimes resulting from partisan competition because the different agencies are led by different political parties (Busch, 2008). In turn, where different actors have different priorities, struggles for resources in multi-actor and interdepartmental settings can be expected: "the agency's commitment to the networked service or activity must be asserted and successfully defended in the face of competing claims from other organizational actors 
for a share of the organization's resources" (O'Toole et al., 1997: 142). It is thus important to distinguish between non-compliance resulting from factors lying outside the SLBs' area of competence (cross-agency political divergence) and non-compliance caused by competing agendas of these street level actors (cross-agency street-level divergence).

The presented evidence shows that the roots of non-compliance can be manifold in multi-actor contexts that include different hierarchy levels and different sectors. Compliance issues can exist when all street-level actors could be willing to comply with policy targets, but missing resources (that are not provided by the political level) reduce their capacity. This is a typical case for political divergence, where the way out of the blockage is an escalation to the political heads of agencies. If this strategy is chosen depends on the responsible person's estimation of the prospects of success and the assessment of the associated risks. If escalation is avoided, non-compliance is the outcome. However, choosing this way of action can be a tactic to pass on the potential blame for non-compliance from the street-level to politicians.

The reaction of the head of agencies have proved to be strongly related to the policies' nature. Comparing the smoking bans in restaurants and in workplaces helps to identify central conditions deciding upon political divergence or convergence: 1 ) The social acceptance of the smoking ban in restaurants is higher than in workplaces; 2) the enforcement in restaurants is more visible than in private companies; 3 ) sectors affected by the ban in the workplace are an electoral clientele that politicians do not want to alienate, whilst the ban in restaurants was often also supported by the restaurants because the policy was the result of a political compromise. Thus, the public salience of the topic in the workplace is politically lower because there never was a huge debate comparable to the case of restaurants, which makes the latter issue riskier for politicians. Overall, the evidence suggests that the head of agency will unblock situations by increasing the SLBs' capacity to act (e.g., allocating resources) in policy areas that are politically less risky for the heads of agencies. This result 
is in line with expectation 1 postulating that cross-agency political convergence tendentially fosters street-level convergence and policy compliance.

However, we only observed political convergence in one out of 12 cases, which illustrates the limited relevance of top-down induced cross-agency collaboration in practice. Moreover, in the respective case, political convergence was the result of bottom-up pressure created by SLBs. This goes in line with the claim in the literature on horizontal coordination that forcing organizations from different sectors to cooperate with "purely top-down, hierarchy-like coordination" is not sufficient in itself (Molenveld et al., 2020b: 18). Expectation 2 proposing that political divergence is associated with street-level non-compliance is also supported, since divergent political priorities at the head of agencies led to at least a temporary blockade of the implementation at the street level. The political divergence opened the door for SLBs of partner agencies to prioritize other tasks more directly associated to their core mission.

Importantly, compliance problems also occur in cases of political indifference, where there is a formal political agreement without explicit political signals to SLBs to implement the measures. Political indifference (as compared to political convergence or divergence) was the most frequent scenario, where it was decided at the street level whether to comply or not. This indicates that divergences between the will of the political level and SLBs leading to non-compliance might be in practice less common than previous literature has indicated, because de facto political indifference was overlooked. Various conditions led to an opposition of the SLBs in non-health-related agencies in situations of political indifference (see Table 1). The arguments of the SLBs to justify their blockage of the enforcement activities were that: 1 ) there existed an already good level of target-group compliance, 2) police and inspectorates lack the legitimacy to implementing public health measures, which are not part of their mission and 3) they had limited resources.

In fact, deficient performance of SLBs is often caused by an interaction of high workload, constrained resources and SLBs' perception that the policy does not make sense (Thomann 2015). Additionally, in 
a situation of scarce resources, cross-agency objectives are often not prioritized, particularly because implementing actors may be confronted with "conflicting control signals" since "objectives cut across vertical control lines" (Molenveld et al., 2020a: 2). As the present study shows, the range of intervening factors is exacerbated in cross-agency settings, and explains the diversity of street-level reactions to political indifference at the top of the agency (i.e., Figure 1). It can thus be asserted that "institutional and legal complexity gives rise to ambiguity and uncertainty, making possible entrepreneurial definitions of the law" (Sheingate's 2007: 19).

In cases of street-level divergence, the disconnection between program responsibility (i.e., head of agency) and implementation responsibility (i.e., at the street level) in the structure of the policy delivery represents a major challenge. Neither does the lead agency of the program have the authority to force SLBs from other agencies to comply, nor have partner agencies direct incentive to collaborate. As argued by Molenveld et al. (2020a: 2) "the coordination of crosscutting policy programs is characterized by diffuse control and accountability arrangements without a clear allocation of responsibility and a lack of strong incentives". In particular, partner agencies may not necessarily benefit from the political credit of successful implementation and even be hurt politically depending on their electoral clientele.

Despite these risks, in most cases, SLBs managed to achieve street-level convergence, even in the (frequent) case of policy indifference. The results indicate various conditions that are conducive to cross-agency street-level convergence. First, a policy can be framed in different ways depending on the SLBs professional background. Second, the agencies required for implementation have to be incorporated early in decision making processes by institutionalizing interagency cooperation. SLB scholars can in this aspect learn much from the literature on interdepartmental and horizontal coordination, which has investigated the importance of institutional design strategies (Alexander, 1998; Hustedt and Danken, 2017) and has stressed that "involving the implementing organizations in the design of the coordination arrangement is important" (Molenveld et al., 2020b: 9). Third, the 
existence of a strong intermediary willing to find compromise at the intersection of the different sectors is of crucial importance. Such individuals can translate specific issues into the professional language of each involved sector to increase the policy's legitimacy. This goes in line with Danken (2017: 207) who found that besides "visible political leadership", also "individual bureaucrats' skills [...] mattered for overcoming departmental resistance". From this perspective, compliance is not only a matter of hierarchy, rules and sanctions, but also of identity, trust and beliefs of policy implementers (Dunlop and Radaelli, 2018: 266). Fourth, the capacity to attribute some of the political credit to the partner agency for the successfully implemented policy is also an important factor fostering political convergence. Those four types of mechanisms help achieve a crucial requirement for the setting up of coordination: breaking the status quo and shaking organizations out of their patterns (Peters, 2015).

As suggested in Expectation 3, indifference at the political level can result in both street-level noncompliance and compliance, depending on the capacity to create a bottom-up dynamic around the issue. Being aware of dynamics happening between SLBs of different agencies might help to consider complex responsibility-capacity constellations. Furthermore, the different types of horizontal coordination and issue-coupling influence the way "conflicts rise to the top level in the policy making process" (Hernes, 2020: 2). Interestingly, we found that a lack of official issue-coupling among agencies, due to political indifference, might also favor policy compliance by allowing street-level convergence and the implementation of potentially unpopular measures out of the spotlight.

Expectation 4 proposed that in case of political indifference, street-level convergence would be hampered by a high agency salience. This expectation was confirmed, especially when strong local economic interests were at stake, coupled with a limited public acceptance of the policy. The policy was then perceived as illegitimate by SLBs from the partner agency, and a whole range of professional norms were put forward to justify non-compliance. On the contrary, a low salience left room for the alignment of SLB's objectives and the establishment of cross-agencies solutions. This shows that SLB's might be sensitive to the social and public salience of an issue even in cases when politicians are not. 
Finally, we did not find any mixed case of political divergence combining with street level convergence-or vice versa-in our study. However, the SLB literature has shown the existence of such vertical mismatches. The application of our conceptual framework to such mismatch cases would allow to further specify the conditions likely to lead to each policy constellation and to refine the model.

\section{Conclusion}

Our study underlined that the formal acceptance of a public policy by the government does not necessarily go with an effective implementation will from all involved parts. Announcement effects constitute a typical feature of political life (Pülzl and Treib, 2007), but the incentive to effectively enforce the public measures proactively afterwards may be insufficient. Thus, in the case of political divergence during the implementation at the level of agencies heads (i.e., political divergence), it is the rule-makers themselves who fail to comply with the rule. This raises a whole series of questions and opens paths for future research, to nuance our understanding of "selective compliance" (Mayntz, 2003).

Second, our results highlight the importance of cross-agency dynamics, and show under which conditions partner agencies can have an interest in implementing a policy program issued by another agency and under which conditions other considerations-such as electorate policies and competing policy objectives-take over. Furthermore, the existence of political indifference during implementation should receive more attention in future. In this scenario, non-compliance does not result of divergence between the political and the street levels, but between two groups of SLBs. Although the literature on street-level bureaucracy tends to focus on the divergence between governance levels (politics vs. street-level), the divergence or convergence effects among SLBs remain understudied (Carpenter and Krause, 2015). The difference between cross-agency political indifference, divergence or convergence, and cross-agency street-level divergence or convergence should be systematically studied. As Peters (2006) and Molenveld et al. (2020a: 2) underline, 
horizontal cooperation between agencies faces important challenges in terms of clientele politics and accountability issues, due to their thematic entrenchment. Possible games between different agencies are more complex in cases of cross-agency policies, which are key for tackling some of the major contemporary societal issues. We therefore argue that a future research agenda should combine the literature on SLBs with research on policy coordination considering challenges that specifically result from inter-agency contexts.

\section{Funding Acknowledgments}

This work was supported by the Swiss Tobacco Prevention Fund (TPF), Federal Office of Public Health (public agency). 
References

Alexander ER (1998) A structuration theory of interorganizational coordination: Cases in environmental management. The international journal of organizational analysis 6(4): 334-354.

Ayres S and Stafford I (2012) Promoting decentralized and flexible budgets in England: Lessons from the past and future prospects. Public Policy and Administration 27(4): 324345.

Busch WL (2008) Managing public agency conflict: Why do public works projects get stalled by conflicts with other public agencies? Journal of Public Works \& Infrastructure 1(3): 269-275.

Carpenter D and Krause GA (2015) Transactional authority and bureaucratic politics. Journal of Public Administration Research and Theory 25(1): 5-25.

Danken T (2017) Coordination of wicked problems: (Unpublished doctoral dissertation), University of Potsdam. Potsdam.

Dunlop CA and Radaelli CM (2018) The lessons of policy learning: Types, triggers, hindrances and pathologies. Policy \& Politics 46(2): 255-272.

Gofen A (2014) Mind the gap: Dimensions and influence of street-level divergence. Journal of Public Administration Research and Theory 24(2): 473-493.

Gofen A (2015) Reconciling policy dissonance: Patterns of governmental response to policy noncompliance. Policy Sciences 48(1): 3-24.

Goodman C, Kachur SP, Abdulla S, et al. (2007) Drug shop regulation and malaria treatment in Tanzania-why do shops break the rules, and does it matter? Health policy and planning 22(6): 393-403.

Gortmaker SL, Swinburn BA, Levy D, et al. (2011) Changing the future of obesity: Science, policy, and action. The Lancet 378(9793): 838-847.

Hassenteufel P (2003) Introduction: Fragmentation administrative et concurrences interinstitutionnelles. Politique européenne(3): 5-8.

Hernes V (2020) Policy preferences and ministerial structures: Immigrant integration governance in Western Europe, 1997-2017. Governance: 1-20.

Huber JD and McCarty N (2004) Bureaucratic capacity, delegation, and political reform. American Political Science Review 98(3): 481-494.

Hulst JR and van Montfort A (2012) Institutional features of inter-municipal cooperation: Cooperative arrangements and their national contexts. Public Policy and Administration 27(2): 121-144.

Hustedt T and Danken T (2017) Institutional logics in inter-departmental coordination: Why actors agree on a joint policy output. Public administration 95(3): 730-743.

Lee C-Y and Glantz S A (2001) The Tobacco Industry's Successful Efforts to Control Tobacco Policy Making in Switzerland: Institute for Health Policy Studies.

Lipsky M (1980) Street-Level Bureaucracy: The Dilemmas of the Individual in Public Service: Russell Sage Foundation.

Mavrot $C$ and Sager F (2018) Vertical epistemic communities in multilevel governance. Policy \& Politics 46(3): 391-407.

May PJ and Wood RS (2003) At the regulatory front lines: Inspectors' enforcement styles and regulatory compliance. Journal of Public Administration Research and Theory 13(2): 117-139.

Maynard-Moody S and Portillo S (2010) Street-level bureaucracy theory. In: Durant RF (ed.) The Oxford handbook of American bureaucracy: Oxford University Press, pp. 252-277. 
Mayntz R (2003) New challenges to governance theory. In: Bang HP (ed.) Governance as social and political communication: Manchester University Press, pp. 27-40.

Meyers MK and Vorsanger S (2003) Street-level bureaucrats and the implementation of public policy. In: Peters BG and Pierre J (eds) Handbook of public administration: Sage, pp. 153-163.

Molenveld A, Verhoest $\mathrm{K}$ and Wynen J (2020a) Why public organizations contribute to crosscutting policy programs: the role of structure, culture, and ministerial control. Policy Sciences: 1-31.

Molenveld A, Verhoest K, Voets J and Steen T (2020b) Images of Coordination: How Implementing Organizations Perceive Coordination Arrangements. Public Administration Review 80(1): 9-22.

Neveu E (2015) Sociologie politique des problèmes publics. Armand Colin.

O'Toole LJ, Hanf KI and Hupe PL (1997) Managing implementation processes in networks. In: Kickert, Walter J.M., Klijn, Erik-Hans and Koopenjan JF (eds) Managing complex networks: Strategies for the public sector: Sage, pp. 137-151.

Palley HA (2006) Canadian abortion policy: National policy and the impact of federalism and political implementation on access to services. Publius: The Journal of Federalism 36(4): 565-586.

Peters BG (2006) Concepts and theories of horizontal policy management. In: Peters BG and Pierre J (eds) Handbook of public policy: Sage, pp. 115-138.

Peters BG (2015) Pursuing Horizontal Management: The Politics of Public Sector Coordination: University Press of Kansas.

Pülzl H and Treib O (2007) Implementing public policy. In: Fischer F, Miller GJ and Sidney MS (eds) Handbook of public policy analysis: CRC Press, pp. 89-107.

Rosser C and Mavrot C (2017) Questioning the Constitutional Order: A Comparison of the French and the US Politics-Administration Dichotomy Controversies After World War II. The American Review of Public Administration 47(7): 737-751.

Sager F, Mavrot C, Hadorn S, Hildbrand L (2020). Kantonsübergreifender Evaluationsbericht kantonaler Tabakpräventionsprogramme. Study commissioned by the Tobacco Control Fund, Swiss Federal Office of Public Health. Center for Public Management, University of Bern, 187 p. DOI: 10.7892/boris.140294

Sager F and Thomann E (2017) Multiple streams in member state implementation: Politics, problem construction and policy paths in Swiss asylum policy. Journal of Public Policy 37(3): 287-314.

Sheingate A (2007) The terrain of the political entrepreneur. Formative acts: American politics in the making: 13-31.

Thomann E (2015) Is output performance all about the resources? A fuzzy-set qualitative comparative analysis of street-level bureaucrats in Switzerland. Public administration 93(1): 177-194.

Torenvlied R (1996) Political control of implementation agencies: Effects of political consensus on agency compliance. Rationality and Society 8(1): 25-56.

Trein P (2017a) Coevolution of Policy Sectors: A Comparative Analysis of Healthcare and Public Health. Public Administration 95(3): 744-58.

Trein P (2017b) A New Way to Compare Horizontal Connections of Policy Sectors: 'Coupling' of Actors, Institutions and Policies. Journal of Comparative Policy Analysis 19(5): 419-34.

Trein P (2017c) Europeanisation beyond the European Union: Tobacco advertisement restrictions in Swiss cantons. Journal of Public Policy 37(2): 113-142. 
Tummers L and Bekkers V (2014) Policy Implementation, Street-level Bureaucracy, and the Importance of Discretion. Public Management Review 16(4): 527-547.

Tummers, L. L. G., Bekkers, V., Vink, E., \& Musheno, M. (2015). Coping during public service delivery: A conceptualization and systematic review of the literature. Journal of Public Administration Research and Theory, 25(4), 1099-1126. 


\section{Supplementary Material I + II}

Dataset

Sager, F., Hadorn, S., \& Mavrot, C. (2017). Evaluation des kantonalen Tabakpräventionsprogramms Thurgau 2014-2017: Bern: Center for Public Management University of Bern, 149. https://doi.org/10.7892/boris.100109

Sager, F., Hadorn, S., Mavrot, C., Wittwer, S., \& Züger, M. Evaluation des kantonalen Tabakpräventionsprogramms Basel-Stadt 2014-2017: Bern: Center for Public Management University of Bern, 151. https://doi.org/10.7892/boris.102341

Sager, F., Hadorn, S., Mavrot, C., \& Züger, M. (2018). Evaluation des kantonalen Tabakpräventionsprogramms Basel-Landschaft 2015-2018: Bern: Center for Public Management University of Bern, 179. https://doi.org/10.7892/boris.116950

Sager, F., Mavrot, C., Hadorn, S., Asticher, L., \& Graf, V. (2020). Évaluation du Programme de prévention du tabagisme du canton du Neuchâtel 2016-2020: Bern: Center for Public Management University of Bern, 172. https://doi.org/10.7892/boris.140299

Sager, F., Mavrot, C., Hadorn, S., \& Demaurex, A. (2017). Évaluation du Programme de prévention du tabagisme du canton du Valais 2013-2016: Bern: Center for Public Management University of Bern. Advance online publication. https://doi.org/10.7892/boris.93382

Sager, F., Mavrot, C., Hadorn, S., Demaurex, A., \& Graf, V. (2017). Évaluation du Programme de prévention du tabagisme du canton de Fribourg 2014-2017: Bern: Center for Public Management University of Bern, 155. https://doi.org/10.7892/boris.105151

Sager, F., Mavrot, C., Hadorn, S., Demaurex, A. M. S., \& Graf, V. (2018). Évaluation du Programme de prévention du tabagisme du canton de Vaud 2014-2017: Bern: Center for Public Management University of Bern, 174. https://doi.org/10.7892/boris.111551

Sager, F., Mavrot, C., Hadorn, S., \& Graf, V. (2017). Évaluation du Programme de prévention du tabagisme du canton du Jura 2014-2016: Bern: Center for Public Management University of Bern, 116. https://doi.org/10.7892/boris.99552

Sager, F., Mavrot, C., Hadorn, S., \& Pleger, L. (2015). Evaluation des kantonalen Tabakpräventionsprogramms Uri 2012-2015: Bern: Center for Public Management University of Bern, 131. https://doi.org/10.7892/boris.70709

Sager, F., Mavrot, C., Hadorn, S., Pleger, L., \& Wicki, M. (2015a). Evaluation des kantonalen Tabakpräventionsprogramms Solothurn 2012-2015: Bern: Center for Public Management, University of Bern, 129. https://doi.org/10.7892/boris.72751

Sager, F., Mavrot, C., Hadorn, S., Pleger, L., \& Wicki, M. (2015b). Evaluation des kantonalen Tabakpräventionsprogramms St.Gallen 2012-2015: Bern: Center for Public Management University of Bern, 123. https://doi.org/10.7892/boris.72892

Sager, F., Mavrot, C., Hadorn, S., Pleger, L., \& Wicki, M. (2015c). Evaluation des kantonalen Tabakpräventionsprogramms Zug 2012-2015: Bern: Center for Public Management University of Bern, 135. https://doi.org/10.7892/boris.71154 


\section{Appendix}

\begin{tabular}{|c|c|c|c|c|c|c|c|c|}
\hline \multirow[t]{2}{*}{ Canton } & \multirow{2}{*}{$\begin{array}{l}\text { Affected } \\
\text { passive } \\
\text { smoke } \\
\text { protection } \\
\text { regulation }\end{array}$} & \multicolumn{3}{|c|}{$\begin{array}{l}\text { Agency holding implementation } \\
\text { responsibility }\end{array}$} & \multicolumn{3}{|c|}{$\begin{array}{l}\text { Actor holding implementation } \\
\text { capacity }\end{array}$} & \multirow{2}{*}{$\begin{array}{l}\text { (Non-) } \\
\text { Compliance } \\
\text { Configuration }\end{array}$} \\
\hline & & Agency & $\begin{array}{l}\text { Head of } \\
\text { agency } \\
\text { party } \\
\text { affiliation }\end{array}$ & $\begin{array}{l}\text { Street-level } \\
\text { bureaucrats }\end{array}$ & Agency & $\begin{array}{l}\text { Head of } \\
\text { agency } \\
\text { party } \\
\text { affiliation }\end{array}$ & $\begin{array}{l}\text { Street-level } \\
\text { bureaucrats }\end{array}$ & \\
\hline Basel-City & $\begin{array}{l}\text { Public } \\
\text { spaces (PS) }\end{array}$ & $\begin{array}{l}\text { Health } \\
\text { Agency } \\
\text { (HA) }\end{array}$ & $\begin{array}{l}\text { Christian } \\
\text { Democratic } \\
\text { Party (CVP) }\end{array}$ & $\begin{array}{l}\text { Health } \\
\text { Prevention } \\
\text { Office }\end{array}$ & $\begin{array}{l}\text { Agency of } \\
\text { Building } \\
\text { and } \\
\text { Transport }\end{array}$ & $\begin{array}{l}\text { Social } \\
\text { Democrati } \\
\text { c Party } \\
\text { (SDP) }\end{array}$ & $\begin{array}{l}\text { Hospitality } \\
\text { Licences } \\
\text { Division } \\
\text { inspectorat } \\
\text { e }\end{array}$ & $\begin{array}{l}\text { Cross-agency } \\
\text { political } \\
\text { convergence }\end{array}$ \\
\hline Baselland & $\begin{array}{l}\text { Workplace } \\
\text { (WP) }\end{array}$ & $\begin{array}{l}\text { Agency } \\
\text { of } \\
\text { Economi } \\
\text { c Affairs } \\
\text { and } \\
\text { Health } \\
\text { (AEAH) }\end{array}$ & $\begin{array}{l}\text { Swiss } \\
\text { People's } \\
\text { Party (SPP) }\end{array}$ & $\begin{array}{l}\text { Health } \\
\text { Promotion } \\
\text { Office (HPO) }\end{array}$ & AEAH & SPP & $\begin{array}{l}\text { Labour } \\
\text { inspectorat } \\
\text { e }\end{array}$ & $\begin{array}{l}\text { Cross-agency } \\
\text { street-level } \\
\text { divergence }\end{array}$ \\
\hline Baselland & PS & $\mathrm{AEAH}$ & SPP & HPO & AEAH & SPP & $\begin{array}{l}\text { Food } \\
\text { inspectorat } \\
\mathrm{e}\end{array}$ & $\begin{array}{l}\text { Cross-agency } \\
\text { street-level } \\
\text { convergence }\end{array}$ \\
\hline Fribourg & WP & $\begin{array}{l}\text { Agency } \\
\text { of } \\
\text { Health } \\
\text { and } \\
\text { Social } \\
\text { Affairs } \\
\text { (AHSA) }\end{array}$ & SDP & $\begin{array}{l}\text { Public } \\
\text { Health } \\
\text { Service } \\
\text { (PHS) }\end{array}$ & $\begin{array}{l}\text { Agency of } \\
\text { Economy } \\
\text { and } \\
\text { Employm } \\
\text { ent }\end{array}$ & CVP & $\begin{array}{l}\text { Labour } \\
\text { inspectorat } \\
\text { e }\end{array}$ & $\begin{array}{l}\text { Cross-agency } \\
\text { political } \\
\text { divergence }\end{array}$ \\
\hline Jura & PS & AHSA & SDP & PHS & $\begin{array}{l}\text { Agency of } \\
\text { Economy } \\
\text { and } \\
\text { Cooperati } \\
\text { on }\end{array}$ & $\begin{array}{l}\text { Liberal } \\
\text { Radical } \\
\text { Party } \\
\text { (LRP) }\end{array}$ & $\begin{array}{l}\text { Hygiene } \\
\text { inspectorat } \\
\text { e }\end{array}$ & $\begin{array}{l}\text { Cross-agency } \\
\text { street-level } \\
\text { divergence }\end{array}$ \\
\hline Neuchâtel & PS & $\begin{array}{l}\text { Agency } \\
\text { of } \\
\text { Finance } \\
\text { and } \\
\text { Health }\end{array}$ & SDP & PHS & $\begin{array}{l}\text { Agency of } \\
\text { the } \\
\text { territorial } \\
\text { developm } \\
\text { ent and of } \\
\text { environm } \\
\text { ent }\end{array}$ & LRP & $\begin{array}{l}\text { Consumer } \\
\text { and } \\
\text { Veterinary } \\
\text { Affairs } \\
\text { inspectorat } \\
\text { e }\end{array}$ & $\begin{array}{l}\text { Cross-agency } \\
\text { street-level } \\
\text { convergence }\end{array}$ \\
\hline Solothurn & PS & $\begin{array}{l}\text { Agency } \\
\text { of Home } \\
\text { Affairs }\end{array}$ & SDP & $\begin{array}{l}\text { Health } \\
\text { Office (HO) }\end{array}$ & $\begin{array}{l}\text { Home } \\
\text { Affairs } \\
\text { Agency }\end{array}$ & SDP & $\begin{array}{l}\text { Food } \\
\text { inspectorat } \\
\mathrm{e}\end{array}$ & $\begin{array}{l}\text { Cross-agency } \\
\text { street-level } \\
\text { convergence }\end{array}$ \\
\hline \multirow[t]{2}{*}{ St.-Gallen } & \multirow[t]{2}{*}{ PS } & \multirow[t]{2}{*}{$\mathrm{HA}$} & \multirow[t]{2}{*}{ SDP } & \multirow[t]{2}{*}{$\begin{array}{l}\text { Office of } \\
\text { Health Care }\end{array}$} & $\mathrm{HA}$ & SDP & $\begin{array}{l}\text { Food } \\
\text { inspectorat } \\
\text { e }\end{array}$ & $\begin{array}{l}\text { Cross-agency } \\
\text { street-level } \\
\text { convergence }\end{array}$ \\
\hline & & & & & $\begin{array}{l}\text { Departme } \\
\text { nt of } \\
\text { Security } \\
\text { and } \\
\text { Justice }\end{array}$ & SDP & $\begin{array}{l}\text { Cantonal } \\
\text { police }\end{array}$ & \\
\hline Thurgau & PS & $\begin{array}{l}\text { Agency } \\
\text { of } \\
\text { Finance } \\
s \text { and } \\
\text { Social } \\
\text { Affairs }\end{array}$ & SPP & $\mathrm{HO}$ & \multicolumn{3}{|c|}{ Municipalities } & $\begin{array}{l}\text { Cross-agency } \\
\text { street-level } \\
\text { divergence }\end{array}$ \\
\hline
\end{tabular}




\begin{tabular}{|c|c|c|c|c|c|c|c|c|}
\hline \multirow[t]{2}{*}{ Canton } & \multirow{2}{*}{$\begin{array}{l}\text { Affected } \\
\text { passive } \\
\text { smoke } \\
\text { protection } \\
\text { regulation }\end{array}$} & \multicolumn{3}{|c|}{$\begin{array}{l}\text { Agency holding implementation } \\
\text { responsibility }\end{array}$} & \multicolumn{3}{|c|}{$\begin{array}{l}\text { Actor holding implementation } \\
\text { capacity }\end{array}$} & \multirow{2}{*}{$\begin{array}{l}\text { (Non-) } \\
\text { Compliance } \\
\text { Configuration }\end{array}$} \\
\hline & & Agency & $\begin{array}{l}\text { Head of } \\
\text { agency } \\
\text { party } \\
\text { affiliation }\end{array}$ & $\begin{array}{l}\text { Street-level } \\
\text { bureaucrats }\end{array}$ & Agency & $\begin{array}{l}\text { Head of } \\
\text { agency } \\
\text { party } \\
\text { affiliation }\end{array}$ & $\begin{array}{l}\text { Street-level } \\
\text { bureaucrats }\end{array}$ & \\
\hline Uri & PS & $\begin{array}{l}\text { Agency } \\
\text { of } \\
\text { Health, } \\
\text { Social } \\
\text { and } \\
\text { Environ } \\
\text { mental }\end{array}$ & LRP & $\mathrm{HO}$ & $\begin{array}{l}\text { Security } \\
\text { Agency }\end{array}$ & SPP & $\begin{array}{l}\text { Cantonal } \\
\text { police }\end{array}$ & $\begin{array}{l}\text { Cross-agency } \\
\text { street-level } \\
\text { convergence }\end{array}$ \\
\hline Valais & PS & $\begin{array}{l}\text { Agency } \\
\text { of } \\
\text { Health, } \\
\text { Social } \\
\text { Affairs } \\
\text { and } \\
\text { Culture }\end{array}$ & SDP & PHS & \multicolumn{3}{|c|}{ Municipal police corps } & $\begin{array}{l}\text { Cross-agency } \\
\text { street-level } \\
\text { convergence }\end{array}$ \\
\hline Vaud & WP & AHSA & SDP & PHS & $\begin{array}{l}\text { Agency of } \\
\text { Economy } \\
\text { and Sport }\end{array}$ & LRP & $\begin{array}{l}\text { Labour } \\
\text { inspectorat } \\
\text { e }\end{array}$ & $\begin{array}{l}\text { Cross-agency } \\
\text { political } \\
\text { divergence }\end{array}$ \\
\hline Zug & WP & $\mathrm{HA}$ & LRP & $\mathrm{HO}$ & $\begin{array}{l}\text { Agency of } \\
\text { Economic } \\
\text { Affairs }\end{array}$ & LRP & $\begin{array}{l}\text { Labour } \\
\text { inspectorat } \\
\text { e }\end{array}$ & $\begin{array}{l}\text { Cross-agency } \\
\text { street-level } \\
\text { convergence }\end{array}$ \\
\hline Zug & PS & $\mathrm{HA}$ & LRP & $\mathrm{HO}$ & $\begin{array}{l}\text { Security } \\
\text { Agency }\end{array}$ & CVP & $\begin{array}{l}\text { Cantonal } \\
\text { police }\end{array}$ & $\begin{array}{l}\text { Cross-agency } \\
\text { street-level } \\
\text { convergence }\end{array}$ \\
\hline
\end{tabular}

